\title{
Institutional strengthening of farmer groups on sustainable intercropping in Majalengka Regency, West Java Province
}

\author{
Siti Sehat Tan, Rima Purnamayan*, Adhe Phoppy WE, Sigid Handoko, Catur Oktivian I.H., \\ and Muhammad Yusron \\ Indonesia Center for Agricultural Technology Assessment and Development, Tentara Pelajar 10, \\ Bogor, West Java, Indonesia
}

\begin{abstract}
The government implements a special effort program (of food selfsufficiency) to achieve national food sovereignty focusing on three commodities (rice, maize, and soybeans). One of the efforts is to increase production with the intercropping pattern (Turiman). The program sustainability must be supported by strong farmer institutions. This study aimed to obtain the information about the farmer groups institution as a strong capital for sustainable farming. This study used a qualitative approach with data related to the assessment problem. This study also used relevant literature to learn the correlation between empirical facts and government programs. The study was conducted in June 2019 in Babakan Village, Majalengka Sub District, Majalengka Regency, West Java Province on 100 respondents. Based on the results, the farmers were still oriented to the monoculture model (maize). The supporting organization as a transformation institution was still very weak as indicated by the organizational structure. The low farmer knowledge on the technology introduced and the farmer group management as a technology transfer agent were still oriented towards monopoly profits. Thus, the Turiman model can be come a consideration for its sustainability. Such conditions require government intervention to achieve the strength farmer group institutions with various appropriate methods, such as assistance in managing organizations and collecting business assets as well as business capital.
\end{abstract}

\section{Introduction}

Agricultural development in the past was directed at achieving high productivity in order to achieve food sustainability. However, such development does not have a strong basis for using available resources [1]. Currently, the national development strategy focuses on natural resource management supported by quality human beings.

In addition to agronomic factors, institutionalization is very important for the sustainability of government programs. Institutionalization is a key factor in regulating the relationship between individuals and groups and the sustainability of a government program. The farmer institution is expected to help the economic gap of farmers, but it has not

\footnotetext{
*Corresponding author: rimacahyo@gmail.com
} 
functioned optimally [2]. The strengthening farmer institutions have not been fully able to improve decisions to adopt an innovation in order to improve welfare. Furthermore, the technology dissemination process will run more smoothly if it is accompanied by understanding and utilizing the potential of institutional elements and farmer status in a process of technology transfer or dissemination of new technology [3].

In order to increase production which ultimately realizes national food sovereignty, the government through the Ministry of Agriculture implements the Special Efforts program (UPSUS) for food self-sufficiency focusing on three commodities, namely, rice, maize, and soybeans. The UPSUS program is focused on increasing production by increasing planted area. The increase in production can be performed through the application of locationspecific technological innovations and an increase in the added planting area (LTT). According to [4], production is soil ability to produce certain crop production in certain soil tillage conditions.

Efforts to increase food production can be performed by intercropping to eliminate land use competition between commodities and as a sustainable solution to limited land. In addition, intercropping can also increase soil fertility, thereby reducing the need for fertilizers.

Based on the description above, this study discussed farmer group institutions as a force for sustainable farming and as capital or efforts to transform agriculture into prosperous farmers.

\section{Methodology}

\subsection{Location and time}

The study was conducted on July 2019 at Cihaur Village, Majalengka Sub District, Majalengka Regency, West Java Povince.

\subsection{Approaches and experimental design}

This study used a qualitative and quantitative approach focused on the actual problem as it was without special treatment and observation (assessment) covering the functional and institutional approach of farmers based on the assumptions of uniformity in farming and trading patterns. This study also conducted interviews based on a list of questions that had been compiled to 100 respondents of the Sindang Makmur farmer group at Cihaur Village, consisting of farmer group members and farmer group administrators.

This study was designed by combining literature review and descriptive research. Descriptive research is a research method to describe current or past phenomena. Descriptive research tends to describe a phenomenon as it is by examining it regularly, prioritizing objectivity, and being carried out carefully, and there is no treatment given or controlled and there is no $\mathrm{H}$ test [5].

The qualitative analysis was carried out based on the data as folloring :

1. Knowledge of respondents about the introduction of intercropping technology

2. Response to intercropping technology

3. Organizations supporting farming activities

4. Farmer group

5. Resources involved as asset holders or venture capital

6. Business network that has been done

7. Partnership 
The knowledge and implementation of Technology Components and Farmers' responses in Intercropping pattern (Turiman) were obtained by interviewing the respondents, the data was tabulated and analyzed using a Liker Scale with the formula as bellow:

$$
\text { Response Value }=\frac{\text { Response Score Obtained }}{\text { Maximum Response Score }} X 100
$$

The knowledge and implémentation of technology components had been using only two groups of answers, namely percentage known and applied, meanwhile farmer responses have criteria, namely strongly agree (SS), agree (S), neither (TT), disagree (KS), and strongly disagree (TS)

\subsection{Data analysis}

This study had used data analysis techniques referring to [6] focusing on data related to problems through the selection stage, namely; (1) data reduction or a process of sorting, focusing on simplification, and transforming rough data from written records in the field. Furthermore, these data were adjusted to the focus of writing; (2) the data were presented in the form of narratives or descriptions that were easier to understand and more communicative.

The next stage is an assessment of various articles related to studies (secondary research) such as literature, scientific publications, and browsing from the internet. This stage is also known as desk or library research.

\section{Results and discussion}

\subsection{The key to intercropping farming sustainability}

\subsubsection{Farmer group}

Farmer group is defined as an institution at the farmer level to organize farmers in carrying out activities [7]. Along with developments, farmer groups are regulated by a circular letter from the Minister of Agriculture, so that farmer groups tend to become formal organizations, there is a shift in the purpose of formation from social groups to task groups [8]. The formation of farmer groups is a process of realizing consolidated agriculture [9].

Farmer group formed because of a strong desire to manage farming, will develop and continue. The social capital owned by the group will be in line with the high level of farmer participation, this is in line with the findings of [10-12], that the high level of participation is due to the high level of social capital in the form of beliefs, norms, cultural similarities, fate, religion and culture.

The success of farming in a farmer group, apart from being determined by the purpose of group formation, there are other factors determining success, both internally and externally. According to [13] in "Group Decision Making: Communication and the Group Process", internal and external factors influence affect the group structure while internally, member characteristics play an important role in group formation. In Sindang Makmur farmer group in Cihaur Village, the formation of farmer groups is based on the similarity of interests and similarity in farming, but the social capital owned is still very weak, so that the formed farmer groups tend not to develop. Activities are more focused only on the cultivation of certain commodities and from time to time do not experience significant changes. 


\subsubsection{Human resources in group}

Human resources is one of the most important factors in an organization or institution, in addition to business capital. Human resources in the context of a farmer group in agriculture are influenced by commitment. Commitment to the organization is a relative strength, where it is characterized by three things, namely 1) acceptance of the values and goals of the organization, 2) readiness and willingness to make serious efforts on behalf of the organization, and 3) the desire to maintain membership within the organization [14]. Hasibuan in [15] also defines human resources as a science and art that regulates the relationship and role of the workforce to be effective and efficient in helping to realize organizational goals. Furthermore, according to [16], human resources are an integrated capability of thinking power and physical power possessed by individuals, thus human resources are the most important capital of every human being so that time, energy and abilities must be utilized optimally for the benefit of the organization, as well as for the benefit of the individual. The management and leadership capacities are major factors for group success [17].

Based on the results, the Sindang Makmur farmer group was still not in accordance with the conclusions presented by [14]. Each group member was still oriented towards individual progress, especially the group leader as a yield collector, not as an organizational leader with an orientation towards advancing the group, so that goals for business management and efficiency are difficult to achieve.

The problems of farmers and farmer groups in Indonesia are (1) the lack of knowledge on production management issues and marketing networks, (2) farmers have not been fully involved in agribusiness activities and are still focused on production activities (online farm), and (3) the role and function of farmer group as a forum for farmers has not run optimally [18].

\subsubsection{Intercropping farming sustainability}

The existence of a farmer group to have a dynamic tendency and move forward cannot be separated from the history of its formation. Farmer groups formed based on the interests of farmers will grow and develop, while farmer groups that grow to be used as tools or containers to receive assistance or subsidies related to government programs will be static. Farmer group is formed to run farming together in improving and developing their farming with participatory principles [19]. The lack of farmer participation in the group shows that the farmer group function is still not running.

Farming support organizations in Cihaur Village are limited to collectors controlled by collected buyer. The farmer group leader services for modern agricultural tools and machinery, maize picking, facilities and production kiosks because there are no sellers of agricultural products and other necessities. The harvest is usually sold directly to the head of the farmer group (as collectors) after harvest.

The driving factor is capital, both fund capital and group assets to move the business not owned by the group. Capital and building assets are controlled by the head of the farmer group. The pull factor (market) has been owned by the farmer group, namely markets outside the village and districts for selling maize. The market is a lever to success if it is supported by managers who have good managerial skills and the ability to build partnerships to expand the market and capital. According to [20], the partnership will guarantee an intensive market share for harvests and higher prices.

The existence of intercropping technology for maize and soybeans introduced at the study site, namely Cihaur Village, empirically has little chance for its sustainability. This is due to the portrait of the farmer group with management who is still managed and controlled by the 
Chairman of the Farmer group, the management is still oriented towards monoculture maize cultivation and business capital as a driving factor has not been owned and managed jointly by the group.

Several important points are the driving and binding factors in the group that become the levers of sustainability, namely (1) Farmer group management is able to open networks or partnerships with several entrepreneurs to market the produce from farmers at prices based on agreements that benefit the farmers (2) Prices of farming products, namely maize for sale at an average price above the market price or through middlemen which generally occur in every place and, (3) Provision of production facilities by farmer groups that can be used by farmers by taking and paying after harvest without interest.

Figure 1 and Figure 2 shown, examples of advanced farmer groups such as in the Sidomulyo farmer group in Yogyakarta are still far from the Sindang Makmur farmer group. To achieve advanced farmer groups condition, government intervention is still needed in mentoring and empowering groups on an ongoing basis, in other words, group institutional penetration is a top priority before a technological innovation introduction program is carried out. However, government intervention is not coercive, but rather facilitates to encourage cohesive institutional growth. [18].

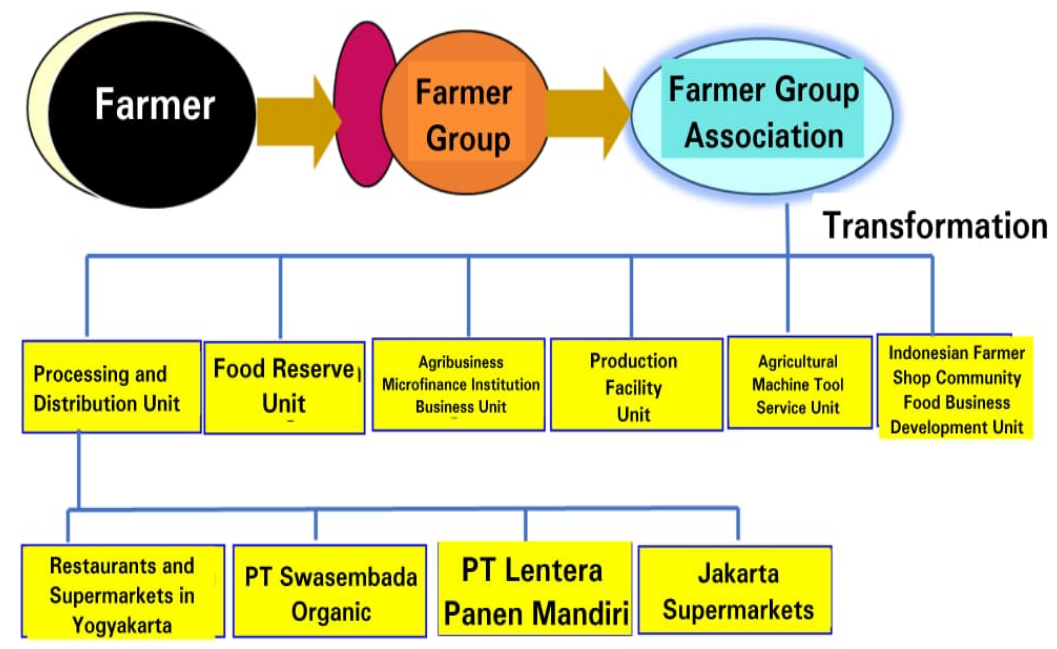

Fig. 1. Transformation of Sidomulyo Farmer Groups Association [22]

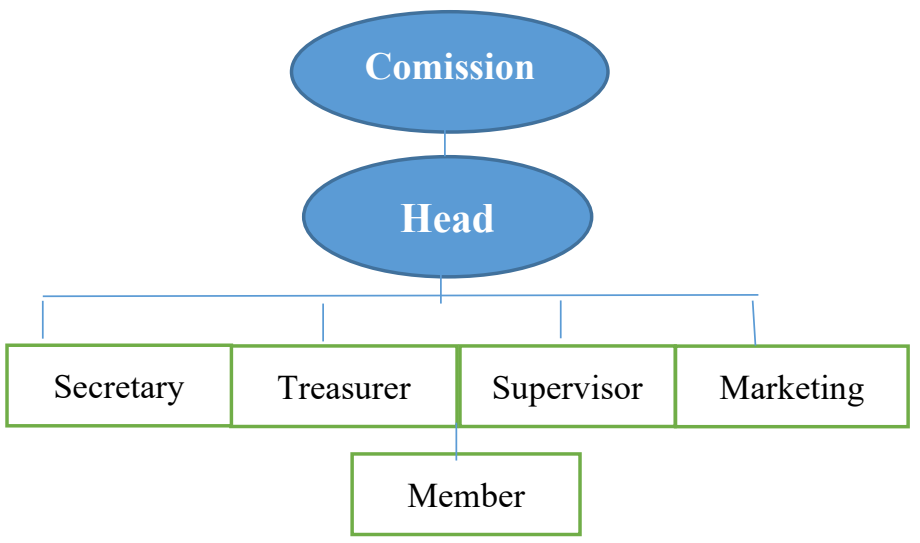

Fig. 2. Structure of Sindang Makmur Farmer Group 
Empirically, intercropping farming sustainability is an impossibility if it is not preceded by institutional strengthening. Basically food crop farmers are smallholders (farmers with land area control of less than $0.5 \mathrm{Ha}$ ). In practice they cannot accumulate profits from the farming process, so that the risk of failure is always avoided if the results provided from the assessment do not provide significant benefits. Farmer institutions contribute to accelerating the socio-economic development of farmers; accessibility to agricultural information; accessibility to capital, infrastructure, and markets; adoption of agricultural innovations, as well as making it easier for the government and other stakeholders to facilitate and provide reinforcement to farmers [2].

Group strengthening is focused on (1) human resources, namely group administrators who have a high commitment to advancing the group, (2) group leaders and administrators consisting of farmers and entrepreneurs, (3) participating capital and other assets facilitated by the government, and (4) making regulations that are binding but beneficial to farmers. Economic activities that benefit all members and organized purchasing of inputs and business tools and control over markets make the group strong [15]. Intercropping model farming will continue if the important points above are fulfilled and financially provide more benefits than the farming that has been done so far. However, institutional evolution or transformation takes a long time so that a sector development program that is longitudinal (multi-year) and consistent in an effort to achieve goals is needed [21].

Intercropping farming will continue if the important points above are met and financially provide more benefits than farming that has been done so far. Empirically, the sustainability of intercropping farming is an impossibility because basically food crop farmers are small farmers (farmers with a land area of less than $0.5 \mathrm{Ha}$ ) who in practice cannot accumulate profits from the farming process so that the risk of failure is always avoided if the results given are assessment does not provide significant benefits.

\subsection{Knowledge and implementation of maize and soybean intercropping technology}

The transfer of knowledge of technological innovation in the early stages is given to the head of the farmer group who is assumed to have intellectual abilities, so that they are able to transfer it to various members by means of their own learning. then transferred to the farmer group members. Knowledge is an intellectual ability and memory in applying concepts for solving problems in the field $[23,24]$

The results of the study on the farmer group above provide a clear picture of the ability of group administrators to transfer the knowledge gained to their members. Based on the data obtained from the respondents after the assessment was carried out (Table 1), it can be seen that farmers' knowledge of several technological components such as the use of new high yielding varieties, use of the number of seeds, tillage, fertilization and maize harvesting has been applied well For generations, farmers in the area have grown maize in monocultures and the private sector has played a significant role in providing knowledge to farmers, related to marketing maize seeds to farmers. However, knowledge of soybean cultivation was very low. 
Table 1. Identification of knowledge and implementation of maize and soybean intercropping technology

\begin{tabular}{|c|c|c|c|}
\hline No & Technology compone & Known (\%) & Implemented (\%) \\
\hline 1 & Use of new high yielding varieties & 100 & 73.33 \\
\hline 2 & $\begin{array}{l}\text { Quality and healthy seeds (purity/certified and germination }> \\
95 \% \text { ) }\end{array}$ & 13.33 & 13.33 \\
\hline 3 & Maize seed needs $40 \mathrm{~kg} / \mathrm{ha}$ and soybean $40 \mathrm{~kg} / \mathrm{ha}$ & 100 & 86.67 \\
\hline 4 & Tillage (plowing $\&$ rotary) using a hand tractor or hoe & 100 & 60.00 \\
\hline 5 & $\begin{array}{l}\text { Downy mildew control. Seed treatment using fungicides with } \\
\text { active ingredients Dimetomorph } 200 \mathrm{~g} / 1 \text { or metalaxyl }\end{array}$ & 80.00 & 13.33 \\
\hline 6 & $\begin{array}{l}\text { Seed treatment of soybeans is carried out with Rhizobium } \\
50 \mathrm{~g} / 5 \mathrm{ltr} \text { of water or using soil from previous soybean plants }\end{array}$ & 0 & 0 \\
\hline 7 & $\begin{array}{l}\text { The plant population is around } 110,000 \text { plants } / \text { ha. Planting } \\
\text { maize as much as } 2 \text { rows of plants with a spacing of } 240 \mathrm{~cm} \\
(60 \mathrm{~cm} \times 12.5 \times 30 \mathrm{~cm}) \text {. The number of plants/holes between } \\
\text { rows is } 67 \& \text { the number in rows is } 800.2 \text { seeds of } \\
\text { maize/hole. Covered with manure } \pm 25-50 \mathrm{~g} / \text { hole }\end{array}$ & 0 & 0 \\
\hline 8 & $\begin{array}{c}\text { Soybean planting is performed } 3 \text { weeks earlier then maize } \\
\text { planting }\end{array}$ & 0 & 0 \\
\hline 9 & $\begin{array}{l}\text { The plant population is around } 310,000 \text { plants/ha. planting } \\
\text { soybeans between maize plants as many as } 7 \text { rows of plants } \\
\text { with a spacing of } 120 \mathrm{~cm}(30 \mathrm{~cm} \times 15 \times 30 \mathrm{~cm}) \text {. Number of } \\
\text { plants/holes between rows is } 233 \& \text { number in rows is } 667.2 \\
\text { seeds of maize/hole }\end{array}$ & 0 & 0 \\
\hline \multirow[t]{2}{*}{10} & $\begin{array}{l}\text { Fertilization of maize is performed twice using basic } \\
\text { fertilizer aged } 10-15 \text { days after planting with a dose of } \\
\text { 15:15:15 namely } 200 \mathrm{~kg} \text { NPK/ha, } 50 \mathrm{~kg} \text { urea/ha, } 150 \mathrm{~kg} \\
\text { SP36/ha by digging }\end{array}$ & \multirow[t]{2}{*}{60.00} & \multirow[t]{2}{*}{60.00} \\
\hline & $\begin{array}{l}\text { 2. The second fertilization at the age of } 28-35 \text { days after } \\
\text { planting. Dosage of NPK 15:15:15 } 200 \mathrm{~kg} / \mathrm{ha} \text { and urea } \\
100 \mathrm{~kg} / \mathrm{ha} \text { by stocking }\end{array}$ & & \\
\hline 11 & $\begin{array}{c}\text { Soybean fertilization is carried out at the age of 10-14 days } \\
\text { after planting with a dose of NPK } 15: 15: 15 \text { 90-129 Kg/ha } \\
\text { and TSP/SP-36 60-90Kg/ha }\end{array}$ & 0 & 0 \\
\hline 12 & $\begin{array}{l}\text { Weeding soybeans manually (pulled) } 1-2 \text { times at the age of } \\
10-15 \text { days after planting \& } 30-40 \text { days after planting }\end{array}$ & 0 & 0 \\
\hline \multirow[t]{2}{*}{13} & $\begin{array}{l}\text { 1. Controlling weeds in maize with selective herbicides } \\
\text { with active ingredients namely Atrazine } 500 \mathrm{gr} / 1 \text { \& } \\
\text { Mesotrion } 50 \mathrm{gr} / 1 \text { at the age of } 10-15 \text { days after } \\
\text { planting. }\end{array}$ & \multirow[t]{2}{*}{20.00} & \multirow[t]{2}{*}{20.00} \\
\hline & $\begin{array}{l}\text { 2. Pilling is performed simultaneously with the second } \\
\text { fertilization or at the age of 21-30 days after planting }\end{array}$ & & \\
\hline \multirow[t]{5}{*}{14} & Harvest & & \\
\hline & $\begin{array}{l}\text { 1. At the age of 60-70 days after planting, leaf pruning is } \\
\text { carried out }\end{array}$ & 100 & 86.67 \\
\hline & $\begin{array}{l}\text { 2. At the age of } 80-90 \text { days after planting, shoots are } \\
\text { pruned }\end{array}$ & 86.67 & 60.00 \\
\hline & $\begin{array}{l}\text { 3. Maize harvesting is performed when the plants are } \\
\text { physiologically ripe, with the leaves dry and yellowish } \\
\text { in color }\end{array}$ & 100 & 100 \\
\hline & $\begin{array}{c}\text { 4. Soybean harvest is done when the main stem is brown } \\
\text { and } 95 \% \text { of the leaves have turned yellow or fall off. } \\
\text { Soybean is yellow or brown \& dries up }\end{array}$ & 0 & 0 \\
\hline
\end{tabular}

Source: Processed primary data

The implementation of maize and soybean intercropping technology aims to improve farmers' knowledge and skills in applying components of intercropping technology. The implementation of the intercropping model is carried out on the group administrator's land with the assumption that the knowledge gained can later be transferred to group members. However, according to farmers, soybean farming is still not optimal and still far from other 
commodities such as rice and maize. Thus, the hope for the sustainability of the model still has to be studied again.

It is confirms that the technology transfer to the farmer group leader has not been able to optimally increase the knowledge of other farmers in the group. It is necessary to provide assistance by the relevant agencies and use of dissemination media. The form of dissemination assistance can be in the form of field meetings, farming courses, technical guidance, plot demonstrations, applied studies, field schools (SL), field visits, group visits, anjangsana and dissemination of information materials. The results of [25], stated that the availability of guides, complementary human resource competencies, dissemination/training media and supporting components (manufacturers and institutions) can significantly increase the production of food source commodities.

\subsection{Response and appreciation to the intercropping technology component}

Farmers at the study sites generally stated that they strongly agreed with the application of the intercropping technology component, however, as usual, farmers avoided the risk of loss if they directly applied the cropping pattern. These doubts are understandable because of limited working capital and farming is the main search so that if there is a failure it will be a risk in their daily lives. The trial conducted on the land of the farmer group management received a good response from the surrounding farmers so that it is expected to be a lesson in increasing knowledge of the application of intercropping planting patterns.

From the survey results, it can be seen that farmers gave a positive response to the technology component of maize cultivation, and gave a negative response to the soybean technology component. Affective response includes acceptance and participation as a stimulus to listen and be active in an activity. The positive response to the technology component in this study only covers maize, which means that the sustainability of the application of maize plant technology is a concern for farmers [26].

The negative response to the soybean technology component is due to the higher local soybean price compared to imported soybeans so that farmers have difficulty selling their soybeans. Besides that, the lack of knowledge and experience of farmers in soybean cultivation makes it increasingly difficult for farmers to accept technology introduction. The solutions to overcome that problems are buyer guarantees, favorable market prices, availability of superior seeds, cultivation technology assistance and capital assistance by the government. Elizabeth [27] states that farmers can protect both as producers by developing, empowering, and strengthening farmer institutions such as farmer groups, labor institutions, input provider institutions, output institutions, capital institutions and extension institutions, so that the realization of sustainability and sustainability of soybean farming. 
Table 2. Response and appreciation to the maize and soybean intercropping

\begin{tabular}{|c|c|c|c|c|c|c|}
\hline \multirow[b]{2}{*}{ No } & \multirow[b]{2}{*}{ Technology components } & \multicolumn{5}{|c|}{ Response and Appreciation } \\
\hline & & $\begin{array}{c}\text { Strongly } \\
\text { agree }\end{array}$ & Agree & Neither & Disagree & $\begin{array}{l}\text { Strongly } \\
\text { disagree }\end{array}$ \\
\hline 1 & Use of new high yielding varieties & & 100 & & & \\
\hline 2 & $\begin{array}{c}\text { Quality and healthy seeds (purity/certified and germination }> \\
95 \% \text { ) }\end{array}$ & & 100 & & & \\
\hline 3 & Maize seed needs $40 \mathrm{~kg} / \mathrm{ha}$ and soybean $40 \mathrm{~kg} / \mathrm{ha}$ & & 86.67 & & & \\
\hline 4 & Tillage (plowing \& rotary) using a hand tractor or hoe & & 100 & & & \\
\hline 5 & $\begin{array}{l}\text { Downy mildew control. Seed treatment using fungicides } \\
\text { with active ingredients Dimetomorph } 200 \mathrm{~g} / 1 \text { or metalaxyl }\end{array}$ & & 100 & & & \\
\hline 6 & $\begin{array}{l}\text { Seed treatment of soybeans is carried out with Rhizobium } \\
50 \mathrm{~g} / 5 \mathrm{ltr} \text { of water or using soil from previous soybean plants }\end{array}$ & & 13.33 & 86.67 & & \\
\hline 7 & $\begin{array}{l}\text { The plant population is around } 110,000 \text { plants } / \text { ha. Planting } \\
\text { maize as much as } 2 \text { rows of plants with a spacing of } 240 \mathrm{~cm} \\
(60 \mathrm{~cm} \times 12.5 \times 30 \mathrm{~cm}) \text {. The number of plants } / \text { holes between } \\
\text { rows is } 67 \& \text { the number in rows is } 800.2 \text { seeds of } \\
\text { maize } / \text { hole. Covered with manure } \pm 25-50 \mathrm{~g} / \mathrm{hole}\end{array}$ & & 86.67 & 13.33 & & \\
\hline 8 & $\begin{array}{c}\text { Soybean planting is performed } 3 \text { weeks earlier then maize } \\
\text { planting }\end{array}$ & & 13.33 & 86.67 & & \\
\hline 9 & $\begin{array}{l}\text { The plant population is around } 310,000 \text { plants/ha. planting } \\
\text { soybeans between maize plants as many as } 7 \text { rows of plants } \\
\text { with a spacing of } 120 \mathrm{~cm}(30 \mathrm{~cm} \times 15 \times 30 \mathrm{~cm}) \text {. Number of } \\
\text { plants/holes between rows is } 233 \& \text { number in rows is } 667.2 \\
\text { seeds of maize/hole }\end{array}$ & & 100 & 86.67 & & \\
\hline 10 & $\begin{array}{l}\text { 1. Fertilization of maize is performed twice using basic } \\
\text { fertilizer aged 10-15 days after planting with a dose of } \\
15: 15: 15 \text { namely } 200 \mathrm{~kg} \mathrm{NPK} / \mathrm{ha}, 50 \mathrm{~kg} \text { urea/ha, } \\
150 \mathrm{~kg} \text { SP36/ha by digging } \\
\text { The second fertilization at the age of } 28-35 \text { days after } \\
\text { planting. Dosage of NPK 15:15:15 } 200 \mathrm{~kg} / \mathrm{ha} \text { and urea } \\
100 \mathrm{~kg} / \mathrm{ha} \text { by stocking }\end{array}$ & & 100 & & & \\
\hline 11 & $\begin{array}{l}\text { Soybean fertilization is carried out at the age of 10-14 days } \\
\text { after planting with a dose of NPK } 15: 15: 15 \text { 90-129 Kg/ha } \\
\text { and TSP/SP-36 60-90Kg/ha }\end{array}$ & & & & & \\
\hline 12 & $\begin{array}{l}\text { Weeding soybeans manually (pulled) 1-2 times at the age of } \\
10-15 \text { days after planting \& } 30-40 \text { days after planting }\end{array}$ & & 13.33 & 86.67 & & \\
\hline 13 & $\begin{array}{l}\text { Controlling weeds in maize with selective herbicides with } \\
\text { active ingredients namely Atrazine } 500 \mathrm{gr} / 1 \& \text { Mesotrion } \\
50 \mathrm{gr} / 1 \text { at the age of } 10-15 \text { days after planting. } \\
\text { Pilling is performed simultaneously with the second } \\
\text { fertilization or at the age of } 21-30 \text { days after planting }\end{array}$ & & 13.33 & 86.67 & & \\
\hline 14 & $\begin{array}{l}\text { 1. At the age of 60-70 days after planting, leaf pruning is } \\
\text { carried out }\end{array}$ & & 100 & & & \\
\hline
\end{tabular}

\section{Conclusions}

The introduction of location-specific technological innovations, namely the maize and soybean intercropping model at the study site with the aim of increasing production by increasing the planting area, has not considered the condition of the farmer group at the study site, where the farmer group is still oriented to the monoculture farming model and is difficult to accept changes to intercropping model. The introduction of intercropping technology innovations (maize and soybeans), is still a consideration for farmers for sustainability. Farmers are generally smallholders who always avoid the risk of loss if the increase in yield with this model is not maximized.

The best approach for farmer groups in the transformation process is a social approach through government intervention. Farmer groups that are formed with the same goal but do 
not have the capital skills in managing and capital/business assets need maximum assistance with various appropriate methods, such as assistance in managing their organization, being a companion in collecting business assets and business capital. Improving the skills of human resources is important to be a concern and target before a program is launched in the area that is the target of activity.

\section{References}

1. S. Pradini, H.S. Alikodra, Hasim, T. Pranaji, International Journal of Development and Economic Sustainability. 4, 2 (2016)

2. S. Anantanyu, Jurnal Sosial Ekonomi Pertanian dan Agribisnis (SEPA). 7, 2 (2011)

3. Khairunnisa, S. Amiruddin, M.S. Oos, Jurnal Penyuluhan. 15, 1 (2019)

4. Nurmala dkk. Pengantar Ilmu Pertanian. Yogyakarta 55283. Graha Ilmu (2012)

5. Furchan. Pengantar Penelitian dalam Pendidikan. Yogyakarta: Pustaka Pelajar Offset (2004)

6. M.B. Miles, A.M. Huberman, J. Saldana, Qualitative Data Analysis, A Methods Sourcebook, Edition 3. (USA: Sage Publication. Terjemahan Tjetjep Rohindi, UI-Press, 2014)

7. Hermanto, Swastika, Analisis Kebijakan Pertanian. 9, 4 (2011)

8. Pelita. Laporan: Kelompok Tani, Ujung Tombak Pertanian Masa Depan. http://www.pelita.or.id/cetakartikel. Diakses pada 4 Mei 2021 (2011)

9. S. Sadjad, Kelompok Tani, Apa Lanjutannya?. http://www.sinartani.com/agriwacana/ kelompoktani-apalanjutannya. Diakses 20 Mei Spetember 2021 (2010)

10. N. Saraswati, AVATRA, e-Journal Pendidikan Sejarah. 4, 3 (2016)

11. N. Yenikawati, et al., Norma Sosial dan Nilai Sosial yang Terkait Usahatani Padi Sawah Desa Lambur Luar, Kecamatan Muaro Sabak Timur, Kabupaten Tanjung Jabung Timur. Sosio (2015)

12. P.P. Egam, M.M. Rengkung, Media Matrasain. 11, 3 (2014)

13. Ellis, Fisher. Small Group Decision Making: Communication and the Group Process, $4^{\text {th }}$ ed. (New York: McGraw-Hill, 1994)

14. Christina, Maren. Journal of International Marketing, (2010)

15. Supomo, E. Nurhayati, Manajamen Sumber Daya Manusia, (Yrama Widya, Bandung, 2018)

16. M. Hasibuan, Organisasi dan Motivasi Dasar Peningkatan Produktivitas. (Jakarta: Bumi Aksara, 2003)

17. T. Nguyen, K. Nguyet. Agricultural Extension Network Updates (AENU). 5, 1 (2002)

18. W. Nasrul, Jurnal Menara Ilmu. 3, 2 (2012)

19. T. Mardikanto, Sistem Penyuluhan Pertanian. (Sebelas Maret University Press. Surakarta, 2009)

20. Susanti. Pengaruh Kemitraan Terhadap Peningkatan Pendapatan Usaha Tani Sayuran, Studi Kasus: Gapoktan Rukun Tani Desa Citapen, Kecamatan Ciawi, Kabupaten Bogor. Skripsi. Institut Pertanian Bogor. Bogor, (2013)

21. K. Suradisastra, Strategi Pemberdayaan Kelembagaan Petani. Jurnal Forum Penelitian Agro Ekonomi. 26, 2 (2008)

22. S.S. Tan, L. Mailena, Empowerment of Farmers Toward Corporate Implementation. E3S Web of Conferences. IConARD 2020, (2021)

23. Kartono. Peningkatan Pengetahuan Penyuluh Tentang Perbanyakan Benih BuahBuahan Melalui Pelatihan di Kabupaten Pandeglang. Prosiding Temu Teknis Jabatan Non Peneliti Bogor. IAARD PRESS. (2015)

24. Baswori, Iskandar. Evaluasi Belajar Berbasis Kinerja. (Karya Putra Darwati. Bandung, 2012) 
25. R. Purnamayani, H. Hermawan, Eksistensi Pendampingan Teknologi Tumpang Saru Tanaman (Turiman) dalam Upaya Peningkatan Produksi Komoditas Sumber Pangan. Prosiding Seminar Nasional Lahan Suboptimal ke-8 "Komoditas Sumber Pangan untuk Meningkatkan Kualitas Kesehatan di Era Pandemi Covid-19". Palembang 20 Oktober 2020, (2020)

26. S.A. Saeko, Respon Petani Padi (Oriza sativa) dalam Penggunaan Pupuk Petroganik di Kecamatan Blora Kabupaten Blora. Skripsi Fakultas Pertanian Universitas Sebelas Maret (2011)

27. R. Elizabeth, Penguatan dan Pemberdayaan Kelembagaan Petani Mendukung Pengembangan Agribisnis Kedelai. Prosiding Seminar Nasional. Dinamika Pembangunan Pertanian dan Pedesaan: Mencari Alternatif Arah Pengembangan Ekonomi Rakyat. Pusat Sosial Ekonomi dan Kebijakan Pertanian (PSEKP). Bogor, (2007) 